www.pasosonline.org

\title{
Cape Verde 2.0: branding and tourism development across the archipelago
}

\author{
Pedro F. Marcelino* \\ Longyearbyen Consulting (Canada) \\ Luzia Oca Gonzaléz* \\ University of Trás-os-Montes (Portugal)
}

\begin{abstract}
This article homes in on the genesis and the development process of tourism in the Cabo Verdes Islands, West Africa, from its definition as a national priority in the post-independence period, to its qualification as a strategic sector in the 1990s, to the prioritizing of the sector as a core economic pillar for the 21s Century. From the analysis of the brand launched by the government in 2010/2011 (One Country, Ten Destinations), the article goes on to dissect several examples of built heritage privatization process, gentrification, and space wars in various islands. While the analysis focuses on Cabo Verde specifically, the country's geographical dynamics and the phenomenology typical of an insular micro-market, allows for a theoretical framework that is applicable to other geographies and contexts.
\end{abstract}

Keywords: Tourism; Cape Verde; Tourist destination.

\section{Cabo Verde 2.0: desarrollo de marca y turismo en todo el archipiélago}

Resumen: El artículo se detiene en el proceso de aparición y desarrollo del turismo en Cabo Verde, desde su definición como prioridad nacional en los tiempos de la independencia, a su consideración de sector estratégico en la década de 90 y de pilar económico en el siglo XXI. A través del análisis de la marca lanzada en 2010/11 por las autoridades (Un país, diez destinos), el trabajo aborda varios ejemplos de procesos de privatización patrimonial, gentrificación y guerras espaciales en las diversas islas. El abordaje del tema en estas ilas, com las dinâmicas y las fenomenologias de un micromercado insular, haz un encuadramento del marco teórico propicio a la aplicacíon a otras geografias y contexto.

Palabras clave: Turismo; Cabo Verde; Destino turístico.

\section{Introduction}

The archipelago of Cape Verde consists of ten volcanic islands located $500 \mathrm{~km}$ west of Dakar, nine of which are inhabited: St. Anthony (Santo Antão), St. Vincent (São Vicente), St. Nicholas (São Nicolau), Sal and Boavista in the Windward (Barlavento) group; Brava, Fogo, Santiago and Maio in the Leeward (Sotavento) group. The country covers a total land area of $4,033 \mathrm{~km}^{2}$ on the outskirts of the Sahelian climate zone. Most islands are mountainous, except for the three easternmost (Sal, Boavista and Maio), which are generally flat and sandy. For a total of 491,683 local inhabitants (INE, 2010), twice as many are estimated to live overseas, as an extensive and engaged diaspora. Santiago is the largest and most populous, followed in size by St. Anthony and St. Vincent in number of inhabitants.

After obtaining its independence from Portugal in 1975, Cape Verde went through fifteen years of single party rule led by the politico-military force of the anticolonial struggle, the PAIGC. This period was marked by an outstanding nation-building effort, despite the partly unfounded fatalistic prophecies

\footnotetext{
* Political Analyst, Longyearbyen Consulting (Toronto, Canada); E-mail: mail@pedromarcelino.com

** Anthropologist, University of Trás-os-Montes (Vila Real, Portugal); E-mail: luziag@utad.pt
} 
of international experts that deemed the newly independent country economically 'unviable'. From 1991 onwards, the various governments consistently banked on opening up the economy and attracting foreign capital and private investment to industries such as tourism, fisheries, energy, transportation, and telecommunications (Piñeira, Oca and Furtado, 2011). In 2007, Cape Verde graduated from the ranks of the Least Developed Countries to the ranks of developing economies, or Middle Income Countries (MIC). While the islands remained largely dependent on external aid, its economy boomed and the income per capita rose to US $\$ 3,438$, three times higher than in 2000. The 2013 Mo Ibrahim Index of African Governance for the first time placed the country $3^{\text {rd }}$ overall (ahead of South Africa), $6^{\text {th }}$ in terms of economic opportunity, and $5^{\text {th }}$ in terms of human development (MIF, 2013).

Services - commerce, new businesses, air transportation, and tourism - are nowadays the main employers, representing 66\% of the GDP in 2008 (BCV, 2014), constituting the backbone of the Cape Verdean economy. Tourism contributed with $60.8 \%$ of all services in 2008 (INE, 2010). The share of tourism in the GDP grew exponentially, from a mere $2 \%$ in 1995 to $10 \%$ in 2003 and $19.4 \%$ in 2008 (BCV, 2014), matching an 11.4\% overall growth in tourism intakes between 2000 and 2008 (INE, 2010). This growth was mostly based on the 'sun and sand' business model aimed at key foreign markets, and attracting particularly British, Portuguese and Italian visitors. Domestic tourism was at $13 \%$ of the total in 2009 (INE, 2010). As an emerging destination the residential option plays a significant role in attracting private foreign investment, focused primarily on Sal and Boavista (Romero-Girón, 2010) ${ }^{1}$.

In spite of the accelerated economic growth since independence, the country exhibits a number of core fragilities. Examples thereof are the excessive dependence on imports, and the logistical difficulties inherent to its territorial discontinuity. Despite the astounding progress in human development over the last few decades, Cape Verdeans also remain inadequately qualified for and mismatched with the job market; the tourism and service industries demand skills and training that are in short supply (Piñeira et al., 2011).

The country markets itself as a tourism destination by showcasing its archipelagic diversity and, as is common with other multi-island jurisdictions (e.g. Baldacchino and Ferreira, 2013), each of the inhabited ten islands appears to share the same stature and lure as the other nine on the official logo. On the identity front, however, and notwithstanding a clear socio-political consistency across the country, a degree of differentiation beyond petty regional rivalries separates Santiago from the other islands. This cultural/identity split establishes it as the centre against which the periphery is measured and defined. Santiago is the most African of the bunch, in light of its early colonisation and centuries of intense slave trade history. Its mestizo inhabitants gradually moved on to Fogo and Brava and would only later (1800-1900s) reach the northern islands, by then still receiving slave workers. Societies with diverse socio-economic bases resulted from these distinct settlement processes: whereas the earlier wave of colonisation was based on a large-property model, the smaller properties of later settlements resulted in a reduced social distance between slaves and slave owners. In some islands, a mestizo commercial elite would eventually emerge, educate itself and start defining and reflecting upon Capeverdeanness as neither African nor European, but somewhere in-between. In contrast, by this stage, Santiago was seen as the refuge of runaway slaves and their descendants, devoid of markers of modernity and urbanity, and closer to its African roots (Fikes, 2006).

These ancient tropes manifest themselves through an ongoing rivalry between Praia (in Santiago), and Mindelo (in St. Vincent), the two largest cities. While the former was made national capital after the abandonment of the settlement of Ribeira Grande (also known as Cidade Velha, 'Old City'), the latter was for decades the islands' thriving cultural capital. After independence, Praia boomed, becoming the principal centre of political, administrative, economic and cultural life, despite recent decentralising efforts (Piñeira et al., 2011).

\section{Marketing $1+10$ brands from the ground up: entangled much?}

Tourism was not embodied as a national priority immediately after independence but would become a strategic sector after the regime change of the 1990s. This process starts with that archipelago's fast-paced embrace of direct foreign investment over the course of that decade. Little more than twenty years down the road, tourism came to be defined as a key economic pillar that had to be designed from scratch. The first Tourism Act (Lei Básica do Turismo) was passed in 1991 (dos Santos, 2012). Two years later, the government created the Special Tourist Zones (Zonas Turísticas Especiais, or ZTEs), then considered the foundation for all the policies in the sector. These areas were defined on the basis 
of their importance for the development of a national tourism industry, and may have two statuses (Romero-Girón, 2010).

The first is that of the Integrated Tourist Development Zones (Zonas de Desenvolvimento Turístico Integrado or ZDTIs), which are spaces slotted for the development of tourist centres of national import. These lands may be subject to territorial expropriation, and severely restrict any constructive or extractive activities. The ZDTIs are currently located in Boavista (3), Maio (3), Sal (4), Santiago (8) and St. Vincent (7). Eighteen of the twenty-five ZDTIs listed in 2009 were created early on, in the 1990s. Some of the most important among them were reconfigured and expanded in the 2000 s, when eight additional areas were defined.

The second is that of the Tourist Reserve and Protection Zones (Zonas de Reserva e Protecção Turística, or ZRPTs), located in areas with significant scenic or natural value. They may or may not be contiguous areas to existing ZDTIs and may also simply be reserved zones pruned for future ZDTI redevelopment. At present, this typology can be found in the islands of St. Vincent, Sal, Boavista, Maio, St. Nicholas and Fogo.

The making of Cape Verde as a 'sun and sand' destination was from the onset premised on the orography of Sal and Boavista, two islands characterised by expansive sandy beaches and sparsely uninhabited spaces. Their populations increased dramatically between 1990 and 2010: Sal skyrocketed from 7,715 to 25,779 inhabitants, fuelled partly by the only international airport in the country for much of the 1990s; Boavista went from 3,452 to 9,162 in the same period. Efforts to diversify the tourist offer over the last decade were anchored in the creation of products with historical, cultural and natural value, the overhaul of airport infrastructures (currently four international and three domestic airports), and the extension of the tourism portfolio to Santiago and St. Vincent.

In 2010, the Tourism Act was redesigned to accommodate planning and execution instruments, among which the four-year Strategic Plan for Tourism Development, reinforced by planning frameworks for each of the ZDTIs. That same year, the government-backed Marketing Plan 2010/2011 sought to brand the archipelago as a global destination composed of multiple island spaces with diverse offerings under the 'one country, ten destinations' umbrella brand. However, by highlighting people, sun, Creole culture, safety, proximity, sports, history, nature and cuisine, the plan effectively fires in every direction, and fails to define real priorities. Nonetheless, it grouped islands together based on their potential for individual promotion. Sal, Boavista, Santiago and St. Vincent are defined as possible individual brands, but simultaneously part of the three strategic groups of islands defined according to market niches.

The 'Sunny Islands' group bundles up Sal, Boavista and Maio together, focusing on sun and sand offerings complemented by nautical sports. Its marketing strategy targets current and potential regional markets: mainly Germany, Italy, United Kingdom, Portugal, Spain, France, Scandinavia, and the Netherlands. The sub-market segments focus on family and couples.

The 'Essence Islands' group includes Santiago and St. Vincent, which are associated with business/ leisure packages and events, complemented by cultural products (history, music, dance and cuisine). It identifies Portugal, France and Cape Verde as current markets, and countries such as Switzerland, Germany, Spain and Italy as potential ones, across four market segments.

The 'Senses Islands' group lumps together every other island, including uninhabited Santa Luzia. This heterogeneous group focuses on a promotional strategy of 'unusual nature', culture and non-aquatic sports. Its three market segments are more limited and aimed primarily at the French and domestic tourists.

\section{Santiago, an insular mainland}

Santiago has always been in centre stage, partly because it hosted both the old and the new national capitals. Nonetheless, the island itself occupied a subordinated mental space for most Cape Verdeans up until independence, mostly for its connotation with characteristics perceived as African, rude and uncultured. Throughout its history, the island was used as a labour reserve feeding the colonial system (Fikes, 2006). In fact, whilst from the mid $19^{\text {th }}$ century onwards - that is, after the abolition of slavery - outmigration was allowed from other islands, in Santiago the authorities supressed it, redirecting population overflows as indentured labourers in extensive plantations in São Tomé and Angola. Upon independence, however, Santiago became the undisputed centre of the archipelago, often growing at the expense of the remaining islands, and indeed playing the role of 'mainland' to them. 
Unlike the sun and sand islands to the northeast, at 273,919 inhabitants spread over $991 \mathrm{~km}^{2}$ (INE, 2010) Santiago is densely populated. Most of these live in the southern coastal plateau around the capital, and the rest in valleys and plateaus further inland.

Praia, the capital, has undergone a hurried process of urbanisation, its population trebling since 1970 and peaking at 132,317 inhabitants in 2010 (INE, 2010). Its growing pains of social inequality and exclusion have started to translate into growing security concerns. Home to many internal migrants from the interior and from other islands, the capital also accommodates a large contingent of foreigners, notably mainland Africans, Chinese, and expats linked to international institutions and companies.

Santiago's tourism identity remained mostly undefined until the 1990s, when the island started to be promoted as a cultural destination, with growing event and business market segments in Praia. The most significant product in the cultural segment is Cidade Velha, particularly since being listed as a UNESCO World Heritage site in 2009 (UNESCO, 2014), although this remains largely unexplored insofar as domestic tourism is concerned, and as a roots/genealogy tourism segment tapping into Cape Verde's extensive diaspora, and west African middle classes (Agunias and Newland, 2012; Holsey, 2004). A calendar of music festivals (KriolJazz, Gamboa) and international meetings and fairs attempts to create demand for the event and business segments, but for the time being appear insufficient to deliver on the image promoted through official channels. However, the island's status as the 'core' of Cape Verde, home to its institutions, company HQs and half of its population, nonetheless make it a mandatory point of passage.

Although the island's extensive coastline also has manifest tourist potential, it is generally degraded for both environmental and social reasons. Sand and gravel extraction is particularly notable in this regard, as an income activity common to the poorest households in the country, which are often women-led. The construction boom from the 1980s onwards aggravated the situation, as a newly independent country was constructed, with Praia at its heart (Oca, 2009). Three decades later, most beaches have virtually disappeared beyond any engineered regeneration. A few - Ribeira das Pratas, Pedra Badejo, Praia Baxu, São Francisco - have escaped under the authorities' watchful eye, and at least Tarrafal is promoted as a beach destination (which has seen better days).

Santiago's eco-tourism and rural tourism potential is obvious, since the island is home to one of the few National Parks (Serra Malagueta) and one of the country's highest peaks (Pico d'Antónia). In recent years, some businesses associated with these market segments have mushroomed across the island, but its overall expression is minimal and poorly articulated. On the contrary, despite an official discourse for the promotion of integrated and sustainable tourism in Santiago, a handful of planned projects suggest the very opposite. ${ }^{2}$ Over the last decade, numerous construction projects aimed at urbanising vast swaths of land in the vicinity of the capital fashioned a mirage of hotels, time-share apartments, golf courses, marinas, artificial beaches and other pharaonic leisure facilities aimed at attracting foreign investors, particularly from the British Isles. Most failed due to their excessive ambition, legal problems related to expropriations and land rights, and the suspension of works following planning infractions. The global economic crisis took care of the few projects that persisted, stymieing construction and leaving a scared landscape of flattened soil and ghost concrete structures.

This haphazard brand and territorial (mis)management creates the impression that Santiago has been sacrificed for the sake of immediate economic growth, seemingly repeating the failed experiences of the Canary Islands, where the collapse of lower quality tourism has already shown how wrong the model was.

\section{Tourism, heritage and community in Cidade Velha}

As mentioned above, Cidade Velha occupies a special place in Santiago's (and Cape Verde's) product portfolio. Its marketability was boosted in 2009 when UNESCO declared it World Heritage, following a decade of architectural interventions. Founded in 1462 as Ribeira Grande of Santiago, it was the site of the colony's earliest settlement, its main slaving entrepôt, the administrative centre for the Guinea Coast, and for a little over two centuries the national capital. The vast collection of ruins and heritage buildings attests to the site's importance within the colonial system. ${ }^{3}$ The significance of the site was initially recognised by the colonial state in the 1960s, when Portugal repaired some of the crumbling structures as it struggled to hold on to the colonies by glorifying its 'civilising' mission. In 1990, the Cape Verdean government designated the Historic Site as National Heritage, and in 1993 a municipal bylaw established strict local construction guidelines, kick-starting a series of conflicts with the population, who by then lived in and around the heritage grounds; an old convent was used by then as a pigsty. ${ }^{4}$ 


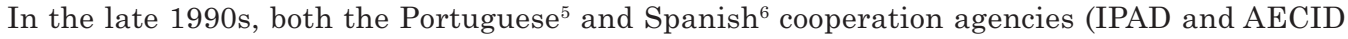
respectively) were brought in to implement heritage protection and restoration projects, after which the government began preparing an application package to UNESCO, following a pre-recovery failed attempt in the mid-1990s. These efforts continued after the 2001 government change and the creation of the Research Institute for Cultural Heritage (IIPC). Its local branch spearheaded an international competition for the recovery of public spaces and historic buildings, in partnership with AECID, who funded the projects. Predictably, a Spanish company (INYPSA) was awarded the contract and conducted the restoration works between 2001 and 2006. The interventions focused on the recovery of built heritage and the development of tourism, particularly in the lower area of the town. An inn designed by the Portuguese star-architect Álvaro de Siza was built in the valley, and a restaurant/bar was opened in Pelourinho Square (pillory). ${ }^{7}$

Figures 5.3, 5.4 and 5.5: Cidade Velha's everyday life. From top-down: fishers in Calhau beach; washing in the street; Pelourinho square.

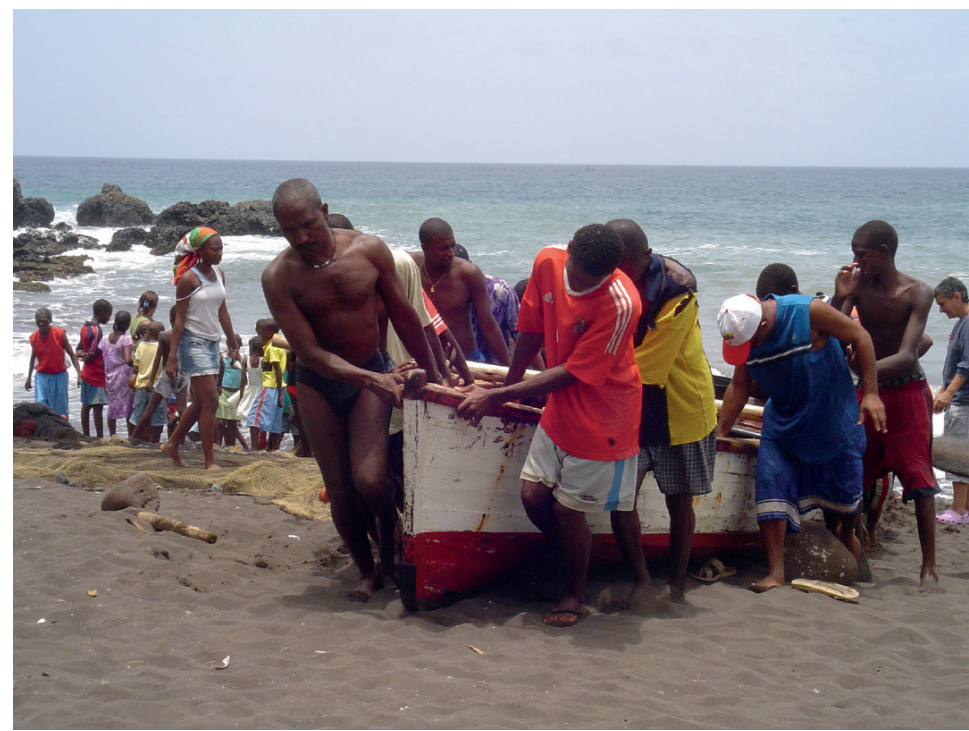

Fuente: Luzia Oca.

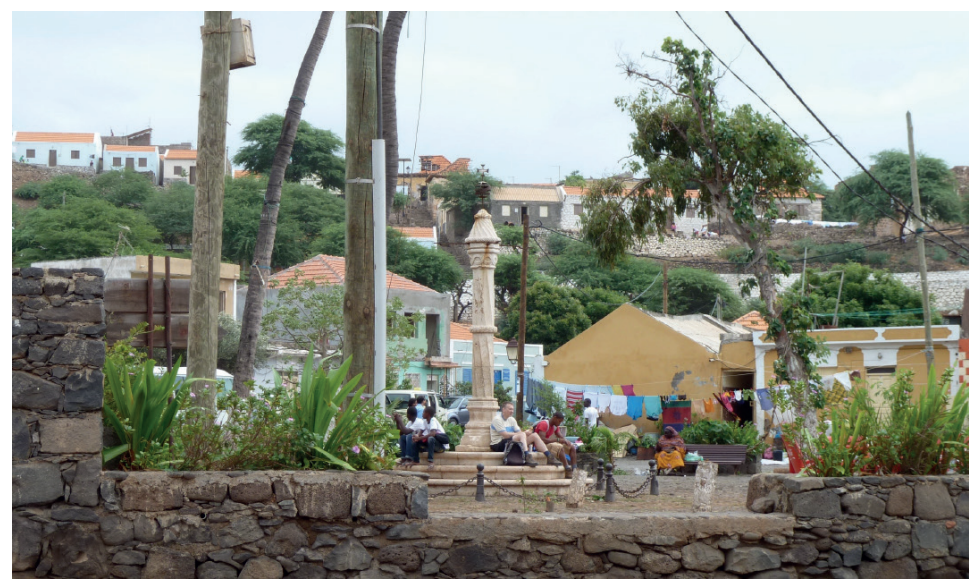

Fuente: Luzia Oca. 


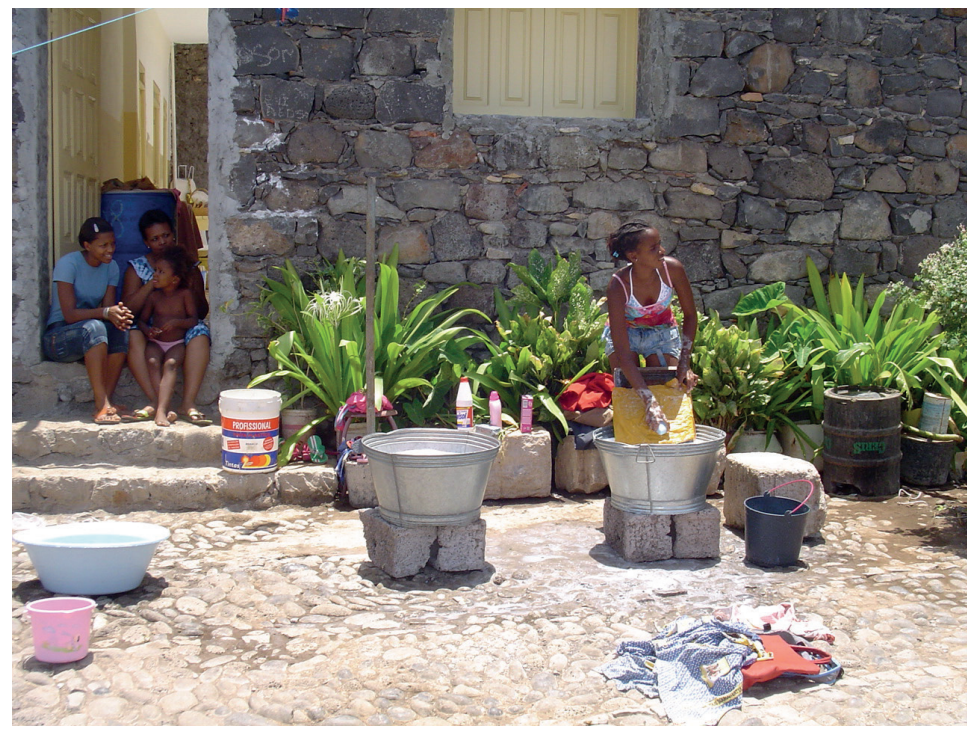

Fuente: Luzia Oca.

In 2006, when the restoration process had been finalised, the Ministry of Culture launched a public tender for the management of the town's tourism resources. Again unsurprisingly, a company with Spanish capital (Proim-Tur) won the contract. Almost unoriginally, one of Proim-Tur shareholders was found to be a leading architect with INYPSA, hinting at insider dealing. This case led to expressions of discontent by much of the local and national population, who felt that their public space had been privatised and handed over to "the Spaniards", now considered "the new owners of Cidade Velha" (De Olho na Praia, 2007). In 2007, AECID opened a Technical Cooperation Office in Praia, and would thereafter implement most of its projects either directly or through NGOs, in collaboration with the IIPC and the municipality. According to its own assessment, their earlier interventions had resulted in few benefits for the local population, due to the lack of a participatory methodology (AECID, 2004). In 2008, as the new UNESCO application package was finalised, the population was for the first time formally heard and taken into account (Gov.CV, 2008). It would have a voice in the future management body, through the site's Ombudsman.

In short, Cidade Velha has been the subject of interventions by various local and exogenous actors, both institutional and private, pursuing different objectives and interests, often at odds with each other. The authors' assessment, based on a decade of community work in Cidade Velha, is that up until 2009 successive projects failed to take the local population into account, resulting in conflicts related to the use of public space, and to building restrictions. The local population did not feel like participants or beneficiaries of the asset recovery process, and often considered the new building standards as unwanted impositions. ${ }^{8}$ An example of this was the resistance of residents of Banana Street to having their roofs traditionally re-thatched, rather than keeping their modern roofs. In another prominent case, the residents of Calhau Street, a row of seafront houses, harshly critiqued the construction of a traditional stone wall over their façades: a cosmetic intervention that made no attempt at improving the residents' lives, even though several houses had no sewage or running water.

Unlike many other World Heritage sites, Cidade Velha is densely populated. The 1,214 inhabitants are clustered around the historic site, occupying a third of the overall protected area (209ha). The town has a high incidence of poverty (38.9\%), unemployment (8\%), and illiteracy (30\%) (INE, 2007). The building restrictions prevented the construction of new houses to households that didn't even have access to buildable land until recently (and only in the upper town). Ironically, the land contiguous to the Historic Site as been allotted to the ZDTI Santiago Resort to the east, and to the ZDTI Achada Santa Marta to the west, both limiting the alternatives for local families, and endangering the visual integrity of the site. In the latter case, real estate speculation resulted in the sale of plots almost exclusively to people and companies with a high purchasing power: national elites, diaspora buyers, and foreigners. As a 
response, the population often contravened the law, expanding their houses or even building new ones, in the hope that finalised structures would be allowed to stand. The municipality's cautious reaction has been to impound any construction sites, but never demolishing structures. Nonetheless, the process has been frayed with allegations of partisanship: since 2008 the main opposition party holds the local municipality, putting it at odds with central authorities sharing jurisdiction over municipal lands. In 2013, the municipality presented the Atxada Forte New Town (Cidade Nova) project (Semana, 2013) to meet the need for land. Its location has been contested, and the population shrewdly questions the existence of the necessary funds. While we cannot refer to a 'space war' just yet, it should be pondered that the arrival of new actors (mostly tourists, but also the capital's urban elites, entrepreneurs and returned migrants) does increase social pressure, leading to the loss of space for native residents' everyday life.

But the lack of local participation was not limited to urban planning. A major flaw has been the inability (or unwillingness) to prepare the local population, which inhabits the tourist space, to run activities that allow them to benefit from the inflow of tourists. Proim-Tur, the concessionary, limits training activity to the personnel required to operate its own circuit and its own supporting businesses. In fact, with few exceptions, no training activity was held for the general population until 2011. Capacity building projects funded by various partners have ensued. But this is too little, too late, since most business licenses already lie with out-of-towners. The rare economic links between the local populations and touristic activity mean locals watch busloads of tourists pass by, barely impacting their lives.

Since 2005, the influx of tourists has increased dramatically: from 1,000 foreigners per year in 2007, to over 30,000 in 2012 and an astounding 15,000 in the first quarter of 2013, according to the Ombudsman (Sapo, 2013). The inclusion of Cidade Velha on UNESCO routes has quadrupled the figures of previous years, although the statistical hike may also be related to a new market segment: cruise ships. ${ }^{9}$ Unfortunately, bus tours are organised by Proim-Tur, who also levies charges for 'its' historic circuit, and preferably directs tourists to its own facilities. Cape Verdeans are charged the same price to visit these national heritage sites as any other visitor (exception is made to the inhabitants of Cidade Velha, after much debate). Ultimately, and sadly, Santiago's cultural tourism brand can only be seen as a missed opportunity and a social-economic flop.

\section{Imposing a mass tourism model in small island communities}

In densely populated Santiago, the by-products of accelerated growth have been the commodification, institutionalisation and privatisation of its (in)tangible cultural heritage. Meanwhile, in St. Vincent, Sal, Boavista, Maio and, to a lesser extent, Fogo, the core issues appear to be gentrification, land tenure, and the dilution of identity - and thus weaker branding. This is, at the end of the day, part of a process that islands, archipelagos, and large cities around the world have undergone, are undergoing, or will undergo, and in which paradises are discovered, occupied, developed, possibilities realised but in which something is necessarily lost (Clark et al., 2007).

European tourists certainly pose a set of challenges to a country undergoing profound social-economic change. The real estate boom has led to large portions of prime land being sold to foreign investors for the construction of gated communities and tourist resorts, at times through allegedly unlawful land seizure by the authorities. These properties - found on, or projected for, almost every island - are owned, marketed, and sold mostly to foreigners, and sometimes to the diaspora, for a premium, which has pushed the prices of land and housing to levels untenable for average Cape Verdeans. This is not only the case with new constructions unaffordable to the middle class, but in some cases already extends to the customary colonial-style housing used by many locals, ${ }^{10}$ and now also out of reach because it has been deemed 'typical', 'picturesque', and thus so desirable that it can be sold for a premium to a foreigner. As a result, much of the prime real estate in Boavista and Sal, and a handful of large colonial properties in the cities of Mindelo (St. Vincent) and São Filipe (Fogo) are increasingly in the hands of foreigners or non-residents whose priority is the valuation of an investment.

Although Cape Verde has never been a "cheap" country in which to live, because of its island nature and import dependency, it has become considerably more expensive with the growth of the tourist industry and the arrival of European residents over the last few years. Cape Verdeans are now coping with ramping inflation, often absurdly priced real estate and inflated commodities, utilities, telecommunications, and air travel prices, and find themselves increasingly out-of-pocket... or out of stock. ${ }^{11}$

Foreigners have been part of the national fabric from the early colonial days. While the Portuguese returned right after 1975, it was not until after the 1991 election that the new climate 
of economic liberalisation and the pro-business atmosphere attracted a significant number of other Europeans: at first adventurous tourists, then investors, and eventually hordes of tourists in search of the newest 'untouched' paradise. As Cape Verde's economy took off to what appeared to be a future promising growth in the real estate and tourism services markets, their numbers skyrocketed. By 2009, thousands were arriving for charter holidays, fewer for tailored travel (eco, solidarity and cultural tourism), and hundreds more had moved from all over Europe to every island. Communities of Europeans are now found in all major cities and towns, and even in the most remote corners of the mountainous island of St. Anthony. ${ }^{12}$ In Sal and Boavista, two islands with relatively few inhabitants but extensive tourist infrastructure, the permanent or seasonal communities of Europeans account for a large slice of the local population. Not necessarily the largest local minorities, they are, however, the most influential, and are perceived as the wealthiest. Many Europeans acquired second homes routinely used for one or two seasons every year. As tourists, Europeans can easily purchase a visa upon arrival; as temporary residents they are allowed to be in the country for six months.

Initially, investors and tourists arrived from Portugal, but were very soon followed by others: Spanish, due to the proximity to the Canaries and a small migrant community in the country; Italian, exploring historical connections with Sal and Boavista, and bypassing the northern European markets that had saturated other islands; French, whose interest spanned from the huge cultural capital of a sizeable Cape Verdean community in Paris, including musical icons such as Cesária Évora; and Dutch and German, who sought off-the-beaten-track adventurous high-mountain thrills in St. Anthony or Fogo. By 2005, the country's reputation had grown across continental Europe, finally reaching the mass market in the United Kingdom when a national travel industry award identified Cape Verde "as one of the few safe and secure holiday destinations in Africa [...] located close enough to Europe to sustain charter tourism," and dubbing it an up-and-coming holiday and second home destination. A number of business missions resulted in significant English, Irish, and Scottish capital being invested in multiple real estate projects in several islands. Although the holiday property market boomed, fuelling the Cape Verdean economy and attracting large quantities of migrant workers, it remains to be seen how the industry will recover from the post-2008 global economic crisis that severely depleted the portfolio of available buyers.

\section{Of gentrification, space wars and non-places}

The island of Sal, former jewel of the crown, has learned this the hard way. Mega-real estate projects both there and in St. Vincent have been hit hard by the global crisis and now stand empty, half-built. Every time a newer, more enthusing island is discovered, the previous is left to dwindle. Sal has lost its monopoly on transatlantic flights. Following this, a significant part of its tourist market simply moved - or moved on - to Boavista. There is little doubt tourists will keep moving until eventually Cape Verde runs out of islands and tourists move elsewhere, unless out-of-the-box marketing and retention strategies help the islands escape this vicious logic and proactively move toward differentiation and customer loyalty.

Meanwhile, on Sal, the tensions are palpable. Local merchants and hoteliers state that street sellers harass tourists to the point of exhaustion and accuse them of establishing a "bad reputation" for the resort island, drastically reducing the return rate (Conde, 2008). Although there is an imposing presence of African mainlanders in Santa Maria, the island's sleepy main town, some of the accusations are not only unfounded, but may constitute scapegoating. The troubles of Sal may have been compounded by the global economic crisis, more so than in any other island. Gigantic mixed-use real estate projects lie half-abandoned across the island like concrete ghosts waiting for the real estate market to take off again and leaving hundreds of migrants now unemployed (Expresso das Ilhas, 2009). More accurately, however, Sal's economic woes most likely lie in its own development model: basic, unoriginal resort tourism that appears to be in decline, just as Boavista - a prettier, wilder island with an edge - ascends to a similar, and higher quality, position. It does not help Sal's case that Boavista now has its own international airport (for charters loaded with wealthy foreigners), while most business traffic was diverted to the capital's revamped Nelson Mandela International Airport (Marcelino, 2013).

Meanwhile, in Boavista, the dire consequences are visible. Here, paradisiacal luxury hotels and affluent residential developments are surrounded by pristine sand dunes peppered with date trees and a $6 \mathrm{~km}$ long insular extension of the Sahara Desert. Once paraded as the country's pearl, Boavista today 
boasts one of the highest costs of living in the country fuelled by its bourgeoning tourism industry and is beginning to exhibit the growing pains of social conflict. Nowhere in the archipelago is the disparity between rich and poor as shocking as in this large and sparsely populated island. While Cape Verdeans lived in simplicity before the touristic boom, their living conditions are now in stark contrast with the über-luxury of the mega-resorts. Not far away, African migrants attracted by construction jobs in the Boavista ZDTI live segregated in the outlying Barraca, a community rife with unemployment, malnourishment, infectious diseases, alcoholism, drug abuse, drug trafficking, as well as petty and violent criminality (Marcelino, 2013). Worryingly, and predictably, as the economic crisis settles in, violent criminality is overflowing from the boundaries of this isolated ghetto to the islands' main urban centre, the sleepy town of Sal Rei, "risking spoiling Boavista's positive image and damaging its tourism potential" (Expresso das Ilhas, 2009). While municipal authorities confess to not having the capability to resolve this urban time bomb - a flagship case for workforce mismanagement - much of the public discourse on Barraca to date seems to revolve around the negative projections to the exterior rather than focus on integration processes.

Yet, the island's woes extend much further. From nary any population just a few years back, Boavista swelled to over 6,000 inhabitants in 2010 (INE, 2010), out of which an estimated 2,800 live in the degraded shantytowns in Salinas and Barraca (Frederico, 2010), and almost all the rest in Sal Rei, the island's main town. In the high season, the island's population spills over the 10,000 mark. Notwithstanding, several resorts are either under construction or have been approved, to accommodate thousands of additional guests. Slowly, but surely, the Boavista ZDTI has transformed the most sparsely populated island in the country into a large sandy resort where Cape Verdeans provide services with limited added value, receive little in the way of community benefits, are themselves subject to European price-points, and have become a vague and exotic background to someone else's holiday pictures. Bizarre examples of this can be found in the Viana Desert, where a small Portuguese company offers 'culture-hungry' tourists the chance to taste the true hospitality of 'Cape Verdean Berber tents' and the exhilarating experience of partaking in a camel caravan led by real 'Cape Verdean Touaregs'. These are, in fact, Senegalese migrants clad in the traditional cyan garments and sheshes (turbans) of their Mauritanian and Malian neighbours are symptomatic sign of visual politics and problematic tourist representations (Wildman, 2004).

As if this wasn't surreal enough, two mega-resorts owned by the Spanish multinational Riu reinforce the theme: Riu Touareg is a tacky pastiche of a typical southern Moroccan sand palace, surrounded by booze-fuelled swimming pools, while in Riu Karamboa, nested between the sea and protected sand dunes, Tatooine chic meets Abu Dhabi grandeur meets the iconic roofs of Timbouktou. Not content with transforming Boavista into an Anywhere, Cape Verde, or what the sociologist Marc Augé (2006) would call a non-place, these architectural gems have taken the island by storm: Timbouktou-inspired domes now deck buildings in Sal Rei (Moassab, 2012).

A few exceptions offer a glimmer of hope that policy makers will wake up and smell the beans: the smart, culturally-sensitive Italian Guesthouse Migrante in downtown Sal Rei is a rare case of quality accommodation set amid local life, and is part of AITR, the Italian Association of Responsible Tourism (Migrante, 2014). Two hours off-roading away, the Spinguera Resort, another Italian hotel, is a low-impact premium eco-lodge built on the ruins of an abandoned village on the rocky side of the island. Service is thoughtful, cultural heritage patent in every detail, water sourced from new wells. A discrete 500-metre path leads down to a pebbly beach where sharks are said to roam. Reading on a hammock is, therefore, encouraged (Boutique Travel Blog, 2013).

From the coast, the hotel is all but invisible. Water sports are available... back at the mega hotels. Both companies are based locally, reinvest locally, and try hard to remain local. But, in a market that favours multinational-owned resorts benefitting from endless tax breaks, directly importing all their supplies and directly exporting all their profits, competition is fierce. At first glance, the Boavista ZDTI fails to value local customs and thus seems both a social failure, and a serious lack of vision.

Right next door, the island of Maio deserves at least a brief note. Up until the early 2000s, it was probably the only one that still felt like Cape Verde in the 1980s: quiet, quaint, $57 \mathrm{~km}$ of uninterrupted beachfront reached by the occasional airplane. This was too good to be left untouched. Rather than leveraging its identity, the government insisted in bunching Maio with Boavista, and slotting it for similar development. In just a few years, half-built luxury villas peppered the cliffs outside Vila do Maio, abandoned during the 2009 economic bust; downtown, a gigantic row of 3-4 story condos have been built right on the pristine beach stretching between the píer and the salt marshes (read: swamp). Within months, predictably, water had to be pumped continuously to prevent them from sinking. Less 
than $2 \mathrm{~km}$ past the marshes, a fenced-in megalomaniac seafront project also lies abandoned. Straw roofed huts reminiscent of French Polynesia and Kenyan-style wall decorations are visible from the beach. Despite these flops, the population of the tiny island rose from 6,754 in 1990 (INE, 1990) to 8,303 in 2000 (INE, 2010). Thousands more are expected to fill new beds over the next decade. The high added-value tourism patent in quality guesthouses, a handful of world-class restaurants (owned by dreamy French, Spanish and Kiwi expats), and even in a colony of a peaceful and mysterious sect (whose members wear white garments reminiscent of the Holy Land circa 10AD), all hint at a missed opportunity to reinforce eco- and cultural tourism alternatives.

Appadurai (2006, p.83) notes that "majorities can always be mobilised to think that they are in danger of becoming minor (culturally or numerically) and to fear that minorities, conversely, can easily become major ..." This fear of dilution of identity is perhaps best illustrated by the situation of Boavista and Maio, often pointed out within Cape Verde as examples of places where the local population has been surpassed by tourists and foreign residents, transforming locals into service providers rather than native residents. According to Appadurai (2006, p. 83) "globalisation intensifies the possibility of this volatile morphing," but the fear of socio-economic loss helps maintain the status quo, at least in the most vulnerable islands.

Meanwhile, and notwithstanding the logistical, marketing, and branding difficulties facing either of them, St. Vincent, St. Anthony (Santo Antão), and Fogo are carving their own niches, cementing a reputation for high quality, diversified tourism alternatives, namely sports and adventure travel, rural and mountain tourism, cultural immersion tourism, responsible and 'solidarity' tourism, or eco-tourism, among other initiatives.

The least developed of this group is Fogo, a poor and emigration-prone island with the second oldest human settlement in the country. The stunning colonial manors and black sandy beaches of the city of São Filipe attract tourists for a day or two, usually on their way to a short trip up to the national park, revolving around a 2,829-metre active volcano. Cultural immersion, community tourism and mountain sports have increased exponentially in the island, but full island circuits are scarce. Few independent travellers ever venture there, with most arriving as part of organised hiking groups, often flying with a private air charter company. The tendency, however, is for the development of an integrated, community-relevant tourist model, to which the neighbouring island of Brava might be better attached if ferry connectivity is streamlined ${ }^{13}$.

St. Vincent, which is vaguely a synonym for Mindelo - the country's second largest city - can easily be a stand-alone destination, much in the way Zanzibar is. With 150 years of a cosmopolitan harbour city history, a unique architectural heritage, and a literary, theatrical and musical tradition spearheaded by internationally renowned Cesária Évora, the Barefoot Diva, it attracts a more interested tourist who stays in local guesthouses, wanders the streets, and engages with the locals in the ubiquitous cafés. S/he might even come across one of Mindelo's most colourful characters: the secretário, the shrewd, unsolicited and often quirky guides, interpreters and facilitators who have been following foreigners around since the time of the steamship. Late each year, yachts crossing the Atlantic also berth in the city's circular harbour.

Like the locals, tourists often pack up and head to St. Anthony, a short ferry ride away, for a few days of Alpine hiking and a trip back in time. Although a couple of resorts have popped up in the island, the majority of the available accommodation is culturally sensitive, focusing on eco- and responsible tourism. Community stays are also popular with hikers, particularly in the most remote areas. Hiker groups will often pay €20/head to sleep under the stars on the flat roof of a family dwelling. A couple of community-led cultural villages (Lagedos, Monte Trigo) have thrived in recent years, and local guides are trained in languages, mountaineering and natural heritage. The development of this market niche has been fuelled by infrastructural projects, notably the international airport in St. Vincent, and improved ferry connections to St. Anthony. The rapport between the two islands works perfectly for the market niche they serve, and they complement each other to create an offer adequate to that type of tourist.

Yet, opposite forces collude to offset these gains, entice some of the local businesses, and annoy the more involved tourists. Cruise ships the size of several city blocks have started to routinely dock at Mindelo. A few dozen tourists will typically stream out into the streets, swarm handcraft stores and invariably end up at the local beach, with the level of interest and cultural sensitiveness that would be expected. Most, however, are loaded into dozens of mini-buses at the port and ferried straight across the island to a beach where they are greeted by sweet cocktails, serenades and 'traditional' dancers wearing Hawaiian-style grass skirts. A single local company monopolises the bus, entertainment and 
restaurant services, outsourcing whatever it cannot provide. A few hours later, as the ship honks twice for the traditional send off, Mindelo life goes back to normal. In recent years, a handful of cruise ships have started to make incursions to the remote west side of St. Anthony, remaining offshore and ferrying a few tourists to the island each time.

These are, thus, very diverse circumstances facing a variety of islands, creating opportunities and threats, but mostly unmatched by the state's manicured but inflexible development plans, zoning and policies. As Clark and his colleagues note in their study of conflicts over island space; which they call "space wars":

Gentrification is an inherently conflict-ridden process characterised by two outstanding features: a marked shift in occupancy upward in terms of class/socio-economic position, and, reinvestment in the built environment (Clark, Johnson, Lundholm and Malmberg, 2007, p.506).

As a direct consequence of this process, those who cannot afford the new spaces are excluded, dislodged and relegated to the outskirts/peripheries. Gentrification is arguably underway in the several Cape Verdean islands, bringing about fundamental conflicts over space, encouraging corruption and creating a degree of animosity toward tourists and investors, seen as hoarders pricing everyone else out (with the connivance of speculating Cape Verdean property holders).

By not tackling the distinct needs and identities of the islands on a case by case basis (with the possible exceptions of the duos Fogo-Brava and St. Vincent-St. Anthony), the government's development plans not only fail to tap into existing resources and high-value niche markets, but also set some of them up with the phenomena of gentrification (St. Sal, Boavista, Vincent, and Fogo), space wars (Boavista, St. Vincent), and the construction of non-descript destinations joining the rank-and-file of non-places scattered around the world (Sal, Boavista, Maio). And non-places, unfortunately, are the places few high-value tourists return to.

\section{The bottom line: lack of strategic foresight or chronic misbranding?}

The current competing touristic development models in Cape Verde were defined over a period of nearly two decades in a stop-gap fashion, more responses to immediate needs rather than components of a master-strategy and a clear direction for the industry. For much of that period, the country faced chronic socio-economic and infrastructural challenges that distinguished it from more developed tourist destinations. Unfortunately, instead of proactively plotting an upgrade by studying and adopting the successful international models of specialised, high value added places such as the Seychelles, The Bahamas or Tobago, Cape Verde buckled under pressure. By the time sustainable tourism ideas took hold, the 'sun and sand' mass tourism model was already grandfathered. The confused (and confusing) branding attempts that followed were, therefore, designed on a flawed basis, sacrificing some of the islands to this kind of tourism, and stopping short of forcing a different kind of investment.

At its most pernicious, this is replicating botched mass tourism models, mutilating the landscape and failing to create a distinctive brand identity. No one knows what defines the Cape Verde brand (or any of its islands and sub-brands, for the matter). In too many cases, the islands were centrally bunched together with others, irrespective of what local aspirations might have been. Most concerning, however, are the social consequences of this centralised approach: while many of the national tourism development projects theoretically contemplate the population, it is necessary to reflect upon the obvious lack of foresight vis-à-vis the real impacts of large residential complexes in islands with a couple thousand inhabitants, or the social tensions derived from space disputes in established urban centres.

From a developmental point of view, training people to serve mass tourism feeds the industry's aspirations, but it does not empower citizens, nor does it prepare communities to own or benefit from it. In the long run, whether it is the remarkable unremarkableness of Sal, or the social conflict in Cidade Velha, imposed tourism models without proper local consultation and socio-economic adjustments have little chance at being sustainable. Misguided branding efforts, unfortunately, are just the tip of the iceberg. National policies cannot bypass nine distinctive island identities for the sake of growth; nor can island identities circumvent existing policies and practices that make a dog's dinner of their individual brands. 


\section{Bibliografia}

AECID

2004. Evaluación del Programa para la Recuperación del Patrimonio Histórico-Arquitectónico y para el Desarrollo Turístico y Agrícola de Cidade-Velha en la República de Cabo Verde. Madrid, Spain: Ministerio de Asuntos Exteriores y Cooperación.

Agunias, D. R., and Newland, K.

2012. Developing a road map for engaging diasporas in development: A handbook for policymakers and practitioners in home and host countries. Washington, DC: IOM and Migration Policy Institute. Appadurai, A.

2006. Fear of small numbers: An essay on the geography of anger. Durham NC: Duke University Press. Augé, M.

2006. Non-places: An introduction to supermodernity. New York: Verso.

$\mathrm{BCV}$

2014. Home page. Retrieved from http://www.bcv.cv. Praia: Banco Central de Cabo Verde.

Boutique Travel Blog

2013. Cape Verdean Paradise at Spinguera Ecolodge. June 4. Retrieved from http://boutiquetravelblog. com/2013/06/04/cape-verdean-paradie-at-spinguera-ecolodge/

Clark, E., Johnson, K., Lundholm, E. and Malmberg, G.

2007. Island gentrification and space wars. In G. Baldacchino (ed.) A world of islands: An island studies reader, pp. 483-505. Charlottetown, Canada and Luqa, Malta: Institute of Island Studies, University of Prince Edward Island and Agenda Academic.

Conde, $\mathrm{M}$.

2008. Comerciantes do Sal descontentes com excesso de Senegaleses: 'Eles extorquem dinheiro às pessoas'. Expresso das Ilhas, 8 July.

De olho na Praia.

2007. 18 August. Retrieved from http://deolhonapraia.blogspot.com.es/2007/08/proim-tur-os-novos-donos-da-cidade.html

DGT

2010. Plano Estratégico para o Desenvolvimento do Turismo em Cabo Verde (2010/2013). Praia: Direção

Geral do Turismo, Ministério de Economia, Crescimento e Competitividade,

Expresso das Ilhas

2009. Assédio e Insegurança Ensombram Turismo. Expresso das Ilhas, 2 September.

Frederico, S.

2010. Boa Vista: estudo desmistifica o Bairro da Barraca. A Semana Online, 26 February.

Fikes, K.

2006. Emigration and the spatial production of difference from Cape Verde. In K. Clarke and D. Thomas (eds.), Globalisation and race, pp. 97-118. Durham NC: Duke University Press.

GovCV

2008. Plano de Gestão da Cidade Velha 2008-2012, Centro Histórico de Ribeira Grande. Praia: Government of Cape Verde, p.76. Retrieved from http://www.cidadevelha-pm.cv/documentos/planopt.pdf?phpMy Admin=bfed44982b3d4d9ce26dea372944ceca

Holsey

2004. Transatlantic Dreaming: Slavery, Tourism, and Diasporic Encounters. In F. Markowitz and A.H. Stefanson (eds.), Homecomings: Unsettling paths of return, pp. 166-182. Lanham MD: Lexington Books. INE

1990. Censo da População. Praia: Instituto Nacional de Estatística. Retrieved from http://www.ine.cv/ INE dadostats/dados.aspx?d=1

2007. Questionário Unificado de Indicadores Básicos de Bem-Estar. Praia: Instituto Nacional de Estatística. Retrieved from http://catalog.ihsn.org/index.php/catalog/102

INE

2010. Censo da População. Praia: Instituto Nacional de Estatística. Retrieved from http://www.ine.cv. IPDT

2010. Plano de marketing para o turismo de Cabo Verde (2011-2013). Praia: Instituto de Turismo, Direção

Geral do Turismo, Ministério do Turismo, Indústria e Energia. 
Marcelino, $\mathrm{P}$.

2013. O novo paradigma migratório dos espaços de trânsito africanos: Inclusão, exclusão, vidas precárias e competição por recursos escassos em países tampão: o caso de Cabo Verde. Praia and Bissau: Ilhéu Editora and Corubal Editora.

Migrante

2014. Migrante Guesthouse. Retrieved from.http://www.migrante-guesthouse.com/en/

Moassab, A.

2012. Território e identidade em Cabo Verde: debate sobre a (frágil) construção identitária em contextos recém independentes no mundo globalizado. Republished by Buala.org. Retrieved from http:// www.buala.org/pt/cidade/territorio-e-identidade-em-cabo-verde-debate-sobre-a-fragil-construcao-identitaria-em-context.

Mo Ibrahim Foundation

2013. 2013 Ibrahim Index of African Governance: Summary. London: Mo Ibrahim Foundation. Retrieved from http://www.moibrahimfoundation.org/downloads/2013/2013-IIAG-summary-report.pdf

Observatório do Turismo de Cabo Verde

2010. Revista, 3. Instituto de Planeamento e Desenvolvimento do Turismo. Retrieved from https:// portoncv.gov.cv/dhub/porton.por_global.open_file?p_doc_id=810

Oca, L.

2009. Informe: Investigación acción participativa. Fortalecimiento de las Capacidades humanas, sociales e institucionales. Madrid: Asociación para la Integración del Menor PAIDEIA, ACCVE, AECID.

Piñeira, M. J., Oca., L. and Furtado, C.

2011. Cabo Verde, um país insular de diáspora na confluência entre a Europa e África. In R. Lois (ed.), Ordenamento e planejamento territorial na África occidental: Cabo Verde, Senegal e Mali, pp. 65-115. Santiago de Compostela: Lóstrego.

Romero-Girón, V.

2010. Informe: Guia Práctica - El Sector del Turismo en Cabo Verde. Praia: Oficina Camaras Canarias/ Proexca en Cabo Verde. Retrieved from http://aws2.nivaria.com/proexca/de/Estudios_de_Mercado/ Cabo_Verde/2010/Guia_Practica_-_PROEXCA.pdf.

Dos Santos, F. L.

2012. Cidade Velha, património mundial e medidas arquitectónicas. Revista de Estudos Cabo-verdianos, 4, pp. 41-57.

Sapo

2013. Quatro anos depois, Cidade Velha Património da Humanidade quer ser destino turístico de eleição. Retrieved from http://noticias.sapo.cv/vida/noticias/artigo/1321144.html.

Semana

2013. Cidade Jardim nasce em Ribeira Grande Santiago. Retrieved from http://asemana.publ.cv/spip. php?article85520\&ak=1.

UNESCO

2014. Global strategy. Paris: UNESCO. Retrieved from http://whc.unesco.org/en/globalstrategy/

Wildman, K.

2004. Picturing Coffee Bay: the visual politics of tourist representations. Postamble, 1(1), 2-10.

\section{Notas}

1 According to the Cape Verdean Touristic Observatory's data, 95\% of the tourist inflow is concentrated in only four islands: Sal (57\%), Santiago (20\%), Boavista (10\%) and St. Vincent (8\%). This is connected to available bed space: $50 \%$ of the country's beds are in Sal, $23 \%$ in Boavista, $11 \%$ in Santiago (Romero-Girón, 2010).

2 For example, a large development is projected for the coastal ZDTI of Achada Rincão, contiguous to the fishing village of Porto Rincão (population 2,000). This currently uninhabited area would receive a housing complex for thousands of tourists, built with Norwegian funds (Piñeira et al., 2011).

3 Architectural gems include the first church built in Africa (1495), the Pillory (1512), the Fortress of São Filipe (1591), a convent (1640) and the ruins of the old cathedral (1700) (UNESCO, 2014).

4 Until 2005, the town and its rural surroundings was under the jurisdiction of the capital, Praia, $15 \mathrm{~km}$ away. Cidade Velha is now the seat of a new municipality.

5 In 1998, via IPAD, the Government of Cape Verde designated the Portuguese architect Álvaro de Siza as coordinator of the Plan for the Protection and Restoration of Monuments in Cidade Velha. IPAD's efforts focused on the consolidation and restoration of the Cathedral. 
$6 \quad$ In 1999, AECID launched the Recovery Program for Architectural Heritage and the Development of Tourism and Agriculture in Cidade Velha, through INYPSA. Its intervention began in the Fortress of São Filipe.

7 This caused an immediate conflict with a family who operated a local bar, and who for years complained publically in posters around the square. The same space now accommodates two seafront bars, ten metres from each other: a local dig attracts Cape Verdeans, while tourists tend to flock to the 'Spanish bar' next door.

8 As featured in the documentary The Architect and the City, directed by Catarina Alves Costa (2004).

9 In 2013, the Port of Praia received 39 ships totaling 26,585 passengers, most of whom spent a few hours in Cidade Velha. See: http://goo.gl/QlrkBM

10 E.g.: Mindelo's colonial houses, known as caza ingles, or 'English house', small but solid street-level constructions, painted with bright colours and often located in the inner city.

11 In a country where goods have to be shipped in, produce is often simply unavailable. Eggs will typically run out just before Christmas, when many emigrants come back on holiday, the coveted Fogo white wine will seldom reach markets outside the capital and Mindelo, and many other products disappear from the shelves weeks at a time. Specific examples would include the scarcity of the local favourites (tuna and swordfish) from the city's fish market, as luxury hotels and restaurants pre-order whatever little stock is available.

12 Many have invested in small businesses servicing the island's booming eco-tourism industry.

13 In mid-November, 2014, for the first time since 1995, the Fogo Volcano erupted. By the time this book went to press, the communities within the perimeter of the crater had been completely erased from the map. This included the local winery, most of the touristic and communal infrastructure, and the iconic Fogo Natural Park HQ building, inaugurated to international acclaim only 8 months prior. The memory of the place was captured on photos by architecture photographer Fernando Guerra: https://fernandoguerra.exposure.co/cabo-verde. This is a major setback to the prominence of eco- and community tourism in Cape Verde, but plans are afoot to start reconstruction. 